\title{
Affidavit Sebagai Alat Bukti Terhadap Perjanjian Jual- Beli Dibawah Tangan Apabila Salah Satu Pihaknya Meninggal Dunia
}

\author{
Ni Kadek Ditha Angreni1, I Nyoman Bagiastra²
}

1Fakultas Hukum Universitas Udayana, E-mail: ditha.kadek@yahoo.com 2Fakultas Hukum Universitas Udayana, E-mail: nyoman_bagiastra@unud.ac.id

\begin{tabular}{l}
\hline Info Artikel \\
\hline Masuk: 3 September 2020 \\
Diterima : 19 November \\
2020 \\
Terbit : 15 Desember 2020 \\
Keywords : \\
Under hand land sale \\
agreement; Proof; Affidavit. \\
\\
\\
Kata kunci: \\
Perjanjian jual-beli tanah \\
dibawah tangan; \\
Pembuktian; Affidavit. \\
Corresponding Author: \\
Ni Kadek Ditha Angreni, \\
E-mail: \\
ditha.kadek@yahoo.com \\
Do.24843/AC.2020.v05.i03.p10 \\
\end{tabular}

\begin{abstract}
Proof of the sale and purchase of land rights without being accompanied by the deed of the Land Deed Author of which one of the parties dies, then in this condition the heir does not recognize the underhand agreementor because he knows that one of the parties who binds himselfhas died, then the other does not fulfilling his achievements. This research will try to examine issues regarding the proof of sale and purchase of land rights that are not proven by the Official Certifier Of Title Deeds if one party dies This research was carried out through a normative legal study method with using statute approach and conceptual approach. Aftergoing through discussion and analysis, finally, it can be concluded that Land purchase agreements made under legal hands under Article 1320 Indonesian Civil Code and fulfill the conditions of the sale and purchase agreements under customary law, but do not necessarily transfer the rights to their land. Proof of agreement on the sale and purchase of land rights made under the hand if one of his parties dies can be done with affidavit.
\end{abstract}

\footnotetext{
Abstrak

Pembuktian terhadap jual beli hak atas tanah tanpa disertai dengan akta PPAT yang salah satu pihaknya meninggal dunia, kemudian pada kondisi ini ahliwaris tidak mengakui perjanjian dibawah tangan tersebutataupun karena mengetahui salah satu pihak yang mengikatdirimeninggal dunia, maka pilah lainnya tidak memenuhi prestasinya. Tulisan ini bertujuan untuk mengkaji mengenai pembuktian jual beli hak atas tanah yang tidak dibuktikan dengan akta PPAT apabila salah satu pihak meninggal dunia. Tulisan ini menggunakan metode penelitian hukum normatif dengan menggunakan pendekatan perundangundangan (statute approach) dan pendekatan konseptual (conseptual approach). Hasil Penelitian menunjukkan bahwa Perjanjian jual-beli tanah yang dibuat dibawah tangan sah menurut Pasal 1320 Kitab Undang-Undang Hukum Perdata dan memenuhi syarat perjanjianjual-beli menurut hukum adat, namun tidak serta merta memindahkan hak atas tanahnya. Pembuktian perjanjian jual-beli hak atas tanah yang dibuat
} 
dibawah tangan apabila salah satu pihaknya meninggal dunia dapat dilakukan dengan affidavit.

\section{Pendahuluan}

Hukum perjanjian sangat bermanfaat dalam memenuhi kebutuhan hidup masyarakat yaitu untuk mengatur hubungan hukum dari mereka yang mengikatkan diri antara satu dengan yang lainnya, suatu perjanjian itu berlaku sebagai undang-undang untuk pihak-pihak yang saling mengikatkan diri dalam perjanjian tersebut, serta menimbulkan suatu hubungan antara dua pihak, dimana hubungan ini dinamakan perikatan.

Dalam melakukan suatu perjanjian terdapat syarat sahnya untuk melakukan perjanjian sebagaimana ketentuan Pasal 1320 Kitab Undang-Undang Hukum Perdata (selanjutnya disebut KUH Perdata) yaitu sebagai berikut :

1. Adanya kesepakatan kedua belah pihak

2. Adanya kecakapan para pihak

3. Adanya suatu hal tertentu.

4. Adanya suatu sebab yang halal.

Syarat pertama dan kedua adalah syarat subjektif, karena mengatur mengenai subjek suatu perjanjian. Jika dalam suatu perjanjian para pihak tidak memenuhi syarat subjektif tersebut, maka perjanjian tersebut dapat dibatalkan. Maka, permohonan pembatalan kepada hakim dapat diajukan jika salah satu pihak ada yang merasa dirugikan. Syarat ketiga dan keempat adalah syarat objektif, karena mengenai objek dari perjanjian. Suatu perjanjian akan dianggap batal demi hukum jika para pihak tidak memenuhi syarat objektif. Hal ini disebabkan karena perjanjian tidak pernah ada dan tidak mengikat para pihak. ${ }^{1}$

Ketentuan mengenai pihak-pihak dalam perjanjian diatur secara sporadik di dalam KUH Perdata, yaitu Pasal 1315, Pasal 1317, Pasal 1318 dan Pasal 1340. Berdasarkan ketentuan tersebut yang dapat disebut sebagai subjek perjanjian adalah pihak-pihak yang mempunyai kaitan dengan dibuatnya suatu perjanjian. KUH Perdata membedakan 3 (tiga) golongan yang termasuk ke dalam subyek perjanjian yaitu :

1. Pihak-pihak yang membuat perjanjian itu sendiri;

2. Para ahli waris dan juga mereka yang mempunyai hak dari padanya, dan:

3. Pihak ketiga.

Salah satu bentuk perjanjian adalah perjanjian jual beli tanah, dalam permbuatan perjanjian jual beli tanah harus berdasarkan Pasal 37 ayat (1) Peraturan Pemerintah Nomor 24 Tahun 1997 Tentang Pendaftaran Tanah (selanjutnya disebut PP Pendaftaran Tanah), dikatakan bahwa "peralihan hak atas tanah melalui jual-beli, tukar menukar, hibah, pemasukan dalam perusahaan dan perbuatan hukum pemindahan hak lainnya, kecuali pemindahan hak melalui lelang hanya dapat

${ }^{1}$ Gumanti, R. (2012). SyaratSahnya Perjanjian (Ditinjau Dari Kuhperdata). Jurnal Pelangi Ilmu, 5(1),1-13. Diakses dari URL: $\underline{\text { http:// ejurnal.ung.ac.id/index.php/JPI/article/view/900/840 }}$ 
didaftarkan jika dibuktikan dengan akta yang dibuat oleh Pejabat Pembuat Akta Tanah (selanjutnya disebut PPAT) yang berwenang menurut peraturan perundang-undangan yang berlaku."

Pasal 1867 KUH Perdata menyatakan pembuktian dengan tulisan dilakukan dengan tulisan-tulisan otentik maupun dengan tulisan-tulisan dibawah tangan. Maka, dalam membuat suatu perjanjian masyarakat bisa membuatnya dalam bentuk akta otentik dan juga dengan akta dibawah tangan, yang akan menjadi alat bukti dalam persidangan apabila salah satu pihak tidak menjalankan prestasinya sesuai dengan kesepakatannya dalam perjanjian.

Suatu jual beli tanah agar dapat dikatakan sah, maka harus memenuhi 2 (dua) syarat, yaitu syarat materiil dan syarat formil: 2

1. Syarat Materil

a. pembeli berhak (memenuhi syarat) membeli tanah yang bersangkutan.

b. penjual berhak menjual kembali tanah yang bersangkutan.

c. tanah hak yang bersangkutan dapat diperjual-belikan dan sedang tidak dalam suatu sengketa.

Jika salah satu syarat materiil ini tidak terpenuhi, misalnya jika penjual tersebut bukan pihak yang mempunyai hak atas tanah yang dijualnya, maka jual beli tanah tersebut batal demi hukum. Tidak terpenuhinya syarat bagi pembeli atau tanah tersebut sedang dalam sengketa, namun tetap dilakukannya perbuatan jual beli tanah maka dapat dikatakan bahwa jual beli atas tanah tersebut tidak sah. Suatu jual beli tanah adalah batal demi hukum jika transaksi jual beli tanah dilakukan oleh pihak yang tidak berhak.

\section{Syarat Formil}

Berdasarkan ketentuan dalam Pasal 37 ayat (1) PP Pendaftaran Tanah sebagaimana disebutkan di atas suatu pendaftaran atas peralihan hak atas tanah karena jual beli baru dapat dilaksanakan jika dilengkapi dengan akta PPAT. Tidak berarti bahwa akta PPAT sebagai syarat pendaftaran peralihan hak atas tanah karena jual beli tidak wajib. Syarat tersebut tetap wajib, kecuali khusus untuk keadaan tertentu sebagaimana diatur dalam Pasal 37 (2) PP Pendaftaran Tanah, karena misalnya tidak adanya PPAT di daerah terpencil. Sebagaimana yang dinyatakan dalam peraturan tersebut bahwa: “Bahwa dalam keadaan tertentu sebagaimana yang ditentukan oleh Menteri, Kepala Kantor Pertanahan dapat mendaftar peralihan hak milik atas tanah yang dilakukan diantara Warga Negara Indonesia yang dibuktikan dengan akta yang tidak dibuat oleh Pejabat Pembuat Akta Tanah, tetapi menurut Kantor Pertanahan tersebut kadar kebenarannya dianggap cukup untuk mendaftar peralihan hak yang bersangkutan."

Namun dalam prakteknya tidak semua ketentuan Pasal 37 ayat (1) dan (2) PP Pendaftaran tanah dijalankan. Beberapa kasus membuktikan bahwa perjanjian yang dibuat dalam bentuk dibawah tangan rentan akan konflik, apabila terjadi sangkalan oleh pihak yang mengikatkan diri tersebut, sebagai contohnya Kasus hukum dalam

\footnotetext{
2 Santoso, U. (2012). Jual Beli Tanah Hak Milik Yang Bertanda Bukti Petuk Pajak Bumi (Kutipan Letter C). Jurnal Perspektif Fakultas Hukum Universitas Airlangga Surabaya, 17(2), 62-69. DOI: http:// dx.doi.org/10.30742/perspektif.v17i2.95
} 
Putusan Nomor: 383/ Pdt.G/2018/PN. Dps merupakan perbuatan hukum perjanjian jual beli tanah dan bangunan yang menyimpangi PP Pendaftaran Tanah berdasarkan Pasal 37 ayat (1). ${ }^{3}$

Pembelian tanah yang dilakukan oleh TARYONO UTOMO dengan MOHAMMAD SOBRI NOMURA pada tahun 2003 di wilayah Kabupaten Badung yang di lakukan di bawah tangan yaitu dengan Surat Keterangan Jual Hilang Sebuah Rumah tertanggal 16 September 2003 yang di tanda tangani oleh TARYONO UTOMO sebagai Pembeli dan MOHAMMAD SOBRI sebagai Penjual yang di saksikan oleh tetangga dari MOHAMMAD SOBRI serta Kepala Lingkungan Br. Suka Duka Celagi.

Bahwa dari sengketa tersebut TARYONO sebagai pembeli yang merasa dirugikan menggugat ke Pengadilan Negeri Denpasar dengan gugatan Nomor: 383/ Pdt.G/2018/PN. Dps, dimana Penggugat mengajukan gugatan terhadap Tergugat sebagai ahli waris dikarenakan Tergugat tidak mengakui perjanjian di bawah tangan yang telah dibuat dengan Orang Tua Tergugat dimana dalam hal ini Tergugat tidak memberikan prestasi sesuai dengan perjanjian yang disepakati oleh para pihak dalam perjanjian tersebut dan penguasaan Sertipikat Hak Milik (SHM) Nomor: 4117 yang dianggap perbuatan melawan hukum.

Pada putusan perkara tersebut hakim berpendapat bahwa perjanjian tersebut sah secara hukum dan telah memenuhi asas terang dan tunai dikarenakan didasarkan atas kesepakatan kedua belah pihak namun tidak berdasarkan hukum positif yang berlaku melainkan berdasarkan hukum adat.

Pasal 19 ayat (1) Undang-Undang Nomor 5 Tahun 1960 tentang Peraturan Dasar Pokok-Pokok Agraria (selanjutnya disebut UUPA) menyatakan "Untuk menjamin kepastian hukum oleh pemerintah diadakan pendaftaran tanah di seluruh wilayah Republik Indonesia menurut ketentuan-ketentuan yang diatur dengan Peraturan Pemerintah." Pendaftaran tanah ini selain itu untuk kepastian hukum status suatu tanah tersebut, juga untuk memberikan perlindungan kepada para pemegang tanah dengan tujuan agar hak atas kepemilikan tanahnya tidak terganggu oleh pihak yang lain yang mempunyai kepentingan terhadap tanahnya. Hal ini sebagaimana termuat dalam Pasal 19 ayat (2) huruf c UUPA, yaitu sebagai berikut: "Pendaftaran tanah dalam Pasal ini meliputi: c. Pemberian surat-surat tanda bukti hak yang berlaku sebagai alat pembuktian yang kuat." Sertifikat dapat digunakan sebagai alat pembuktian, hal ini sesuai dengan ketentuan pada Pasal 1 angka 20 PP Pendaftaran Tanah, yaitu menyatakan bahwa: "Sertifikat adalah surat tanda bukti hak sebagaimana dimaksud dalam Pasal 19 ayat 2 huruf c UUPA untuk tanah, hak pengelolaan tanah wakaf, hak milik atas satuan rumah susun dan hak tanggungan yang masing-masing sudah dibukukan dalam buku tanah yang bersangkutan."

Berdasarkan kasus tersebut, maka terdapat kekaburan norma mengenai pembuktian terhadap jual beli hak atas tanah tanpa disertai dengan akta PPAT yang salah satu pihaknya meninggal dunia, kemudian pada kondisi ini ahli waris tidak mengakui perjanjian dibawah tangan tersebut ataupun karena mengetahui salah satu pihak yang

3Putusan Nomor : 383/ Pdt.G/2018/PN. Dps. Tersedia di https:// putusan3.mahkamahagung.go.id/direktori/putusan/5258a86b48ea4db2939cfdbc163 7a40e.html. Diakses 14 Juli 2020, pukul 09.00 WITA. 
mengikat diri meninggal dunia, maka pihak lainnya tidak memenuhi prestasinya. Mengingat Pasal 37 (1) PP Pendaftaran Tanah telah jelas mengatur agar peralihan hak atas tanah dapat didaftarkan maka jual beli harus dibuat dengan akta PPAT. Namun terdapat kekaburan norma pada Pasal 37 (2) PP Pendaftaran Tanah yaitu mengenai "keadaan tertentu" dan "akta yang tidak dibuat oleh PPAT tetapi yang menurut Kepala Kantor Pertanahan tersebut kadar kebenarannya dianggap cukup untuk mendaftar pemindahan hak yang bersangkutan."

Tulisan ini akan berusaha mengkaji permasalahan mengenai pembuktian jual beli tanah tanpa disertai akta PPAT yang salah satu pihaknya meninggal dunia. Dalam hal untuk mendapatkan jawaban dari persoalan tersebut, diperlukan uraian mengenai keabsahan hukum perjanjian dibawah tangan serta upaya-upaya apa saja yang para pihak dapat lakukan untuk membuktikan perjanjian jual-beli di bawah tangan apabila salah satu pihak meninggal dunia.

Tulisan ini menggunakan 2 (dua) tulisan terdahulu menjadi perbandingan, antara lain:

1. Jurnal yang ditulis oleh Endah Puspita Sari, Sihabudi, dan Bambang Winarno, yang diterbitkan oleh Program Magister Kenotariatan Pasca Sarjana Fakultas Hukum Universitas Brawijaya. Judul "Kekuatan Pembuktian Affidavit Sebagai Alat Bukti Surat". Permasalahan yang diangkat yakni mengenai Bagaimana kekuatan pembuktian affidavit sebagai alat bukti surat?4

2. Jurnal yang ditulis oleh Ayu Riskiana Dinaryanti, yang diterbitkan oleh Jurnal Ilmu Hukum Legal Opinion. Judul “Tinjauan Yuridis Legalisasi Akta Di Bawah Tangan Oleh Notaris". Permasalahan yang diangkat yakni mengenai Bagaimanakah penerapan legalisasi oleh Notaris? dan Bagimanakah tanggungjawab Notaris atas kebenaran akta di bawah tangan yang dilegalisainya ?5

Dari pemaparan tersebut dapat ditarik perbedaan antara penelitian terdahulu dengan penelitian yang dilakukan oleh penulis. Penelitian yang akan penulis lakukan mengangkat permasalahan mengenai pembuktian terhadap jual beli hak atas tanah tanpa disertai dengan akta PPAT yang salah satu pihaknya meninggal dunia, kemudian pada kondisi ini ahli waris tidak mengakui perjanjian di bawah tangan tersebut ataupun karena mengetahui salah satu pihak yang mengikat diri meninggal dunia, maka pihak lainnya tidak memenuhi prestasinya.

\section{Metode Penelitian}

Metode yang digunakan dalam tulisan ini yaitu metode penelitian hukum normatif karena dalam tulisan ini terdapat kekaburan norma6, kemudian menggunakan dua pendekatan, yaitu pendekatan perundang-undangan dan pendekatan konseptual.

4 Sari, E. P., Sihabudin., \& Winarno, B. (2015). Kekuatan Pembuktian Affidavit sebagai Alat Bukti Surat. Jurnal Hukum, 1-22. Diakses dari URL: http://hukum.studentjournal.ub.ac.id/index.php/hukum/article/view/1194/1180

${ }_{5}^{5}$ Dinaryanti, A. R. (2013). Tinjauan Yuridis Legalisasi Akta Di Bawah Tangan Oleh Notaris. Jurnal Ilmu Hukum Legal Opinion, 1(3), 2. Diakses dari URL: https://www.neliti.com/publications/150428/tinjauan-yuridis-legalisasi-akta-di-bawahtangan-oleh-notaris

6 Diantha, I. M. P. (2016). Metodologi Penelitian Hukum Normatif dalam Justifikasi Teori Hukum. Jakarta: Prenada Media. h. 12. 
Pendekatan ini digunakan dengan tujuan untuk menguraikan suatu argumentasi dalam hal menjawab permasalahan hukum dalam penelitian ini. Pendekatan perundang-undang yaitu "suatu pendekatan yang dilakukan terhadap berbagai aturan hukum yang terkait." Pendekatan Konseptual adalah "suatu pendekatan yang beranjak dari pandangan-pandangan ahli dan doktrin-doktrin yang digunakan untuk memahami konsep-konsep tentang politik hukum." Pendekatan konsep dimaksudkaan untuk menganalisa bahan hukum sehingga dapat diketahui makna yang terkandung pada istilah-istilah hukum. ${ }^{7}$

Untuk membahas permasalahan dalam tulisan ini menggunakan bahan hukum, yaitu berupa bahan hukum primer berupa KUH Perdata, UUPA, dan PP Pendaftaran Tanah. Selanjutnya, menggunakan bahan hukum sekunder terdiri dari literatur hukum yang mempunyai kaitannya dengan persoalan hukum yang diangkat.

\section{Hasil Dan Pembahasan}

\subsection{Keabsahan Perjanjian Jual Beli Tanah yang Dibuat di Bawah Tangan.}

Dalam ketentuan hukum adat, perjanjian jual-beli tanah adalah "suatu perbuatan pemindahan hak atas tanah yang bersifat terang dan tunai." Dalam perpindahan hak atas tanah tersebut dilakukan serentak terjadi begitu pembayaran harga diserahkan kepada penjual. Dapat diuraikan sifat jual-beli tanah terang dan tunai sebagai berikut: ${ }^{8}$

\section{a. Kontan atau tunai}

Dalam hal melakukan pembayaran telah disepakati bahwa harga tanah tersebut dapat membayarkan secara sebagian terlebih dahulu atau langsung seluruhnya. Pembayaran harga dan penyerahan haknya dilakukaan pada saat yang bersamaan, selanjunya jual beli menurut hukum adat telah selesai. Pembayaran harga tanah yang sebagian, menurut hukum dianggap telah dibayar penuh oleh pihak yang memiliki prestasi untuk itu ketika bersamaan dilakukan dengan penyerahan haknya, namun sisa harga yang belum dibayar dianggap sebagai suatu hutang pembeli kepada bekas pemilik tanah setelah penyerahan haknya dilakukan.

\section{b. Terang}

Seorang pembeli agar mendapatkan pengakuan dari masyarakat setempet sebagai pemilik tanah yang baru, serta adanya perlindungan hukum terhadap pembeli atas gugatan yang diterimanya dari pihak yang mempunyai itikad tidak baik, maka jual beli tanah tersebut dilakukan dihadapan kepala desa atau kepala adat.

Lain halnya dengan hukum adat, dalam Hukum Perdata, perjanjian jual beli harus memenuhi ketentuan Pasal 1320 KUH Perdata mengenai syarat sahnya suatu

${ }^{7}$ Hajar, M. (2015). Model-Model Pendekatan Dalam Penelitian Hukum dan Fiqh. Pekanbaru: UIN Suska Riau. h. 41.

8 Widiadnyani, I. G. A., Windari, R. A., \& Suditmaka, K. (2018). Implikasii Yuridis Jual Beli Tanah Adat Melalui Perjanjian Dibawah Tangan Dalam Perspektif Undang-Undang Pokok Agraria. Jurnal Komunitas Yustitia, 1(1). 1-10. Diakses dari URL: https://ejournal.undiksha.ac.id/index.php/jatayu/article/view/23753/14393 
perjanjian. Ketentuan pasal tersebut menentukan bahwa perjanjian untuk dapat dikatakan sah harus memenuhi syarat-syarat sebagai berikut:

\section{Kesepakatan kedua belah pihak}

Adanya kata sepakat diantara para pihak maksudnya bahwa kedua belah pihak yang mengadakan perjanjian setuju atau mencapai kata sepakat mengenai hal-hal pokok dari perjanjian. Kesepakatan disini adalah adanya rasa ikhlas atau saling memberi dan menerima atau sukarela diantara pihak-pihak yang membuat perjanjian tersebut. 9 Dalam Pasal 1321KUHPerdata juga mengatur bahwa "tiada sepakat yang sah apabila sepakat itu diberikan karena kekhilafan atau diperolehnya dengan paksaan atau penipuan".

\section{Adanya kecakapan para pihak.}

Hal ini dimaksud bahwa "cakap untuk membuat perjanjian" menurut ketentuan hukum yaitu telah dewasa dan tidak dalam pengampuan. Adanya suatu hal tertentu. Pasal 1329 KUH Perdata bahwa setiap orang adalah cakap untuk membuat perikatanperikatan, kecuali apabila menurut undang-undang dinyatakan tidak cakap. Pasal 1330 dalam KUH Perdata yaitu:

1. orang-orang yang belum dewasa;

2. mereka yang ditaruh di bawah pengampuan.

3. Adanya suatu hal tertentu.

Maksud dari "adanya suatu hal tertentu" dapat diketahui dengan mengkaji ataupun menelaah salah satu pasal dalam rumusan KUH Perdata, yaitu Pasal 1333, yang menyatakan: "Suatu persetujuan harus mempunyai sebagai pokok suatu barang yang paling sedikit ditentukan jenisnya. Tidaklah menjadi halangan bahwa jumlah barang tidak tentu, asal jumlah itu terkemudian dapat ditentukan dan dihitung."

4. Suatu sebab yang halal.

"Suatu sebab yang halal" maksudnya dalam dibuatnya suatu perjanjian tidak diperbolehkan bertentangan dengan undang-undang, kesusilaan dan ketertiban umum. Uraian lebih mendalam mengenai hal ini dapat ditemukan dalam ketentuan Pasal 1335 dan 1337 KUH Perdata.

Syarat pertama dan kedua adalah syarat subjektif, karena mengatur mengenai subjek perjanjian. Apabila para pihak tidak memenuhi syarat subjektif, maka perjanjian yang telah dibuat dapat dibatalkan, dengan mengajukan permohonan pembatalan kepada hakim yang dilakukan oleh pihak yang merasa dirugikan. Syarat Ketiga dan keempat adalah syarat objektif, karena mengenai objek dari perjanjian. Apabila para pihak tidak memenuhi syarat objektif, maka perjanjian tersebut akan dianggap batal demi hukum, karena perjanjian ini dianggap tidak pernah ada dan tidak akan mengikat para pihak.

\footnotetext{
9 Salim,H.S. (2014). Perancangan Kontrak dan Memorandum of Understanding (MOU). Edisi Ke-6. Jakarta: Sinar Grafika, h.26.
} 
Suatu jual beli tanah dianggap sah jika memenuhi syarat materiil dan syarat formil, yang mana syarat meteriil terdiri dari: (1) pembeli berhak (memenuhi syarat) membeli tanah yang bersangkutan; (2) penjual berhak menjual kembali tanah yang bersangkutan; dan (3) tanah hak yang bersangkutan boleh diperjualbelikan dan tidak sedang dalam sengketa. Syarat formil ditegaskan dalam Pasal 37 ayat (1) dan ayat (2) PP Pendaftaran Tanah yang harus ditempuh agar peralihan hak atas tanah dapat didaftarkan. Pasal 37 ayat (2) PP Pendataran tanah menyatakan bahwa kepala kantor pertanahan kabupaten/kota dapat melakukan pengalihan dan pendaftaran hak atas tanah tanpa adanya akta PPAT. Artinya syarat peralihan hak atas tanah dengan akta PPAT tersebut tetap berlaku, hanya dikecualikan bagi daerah-daerah terpencil yang tidak ada PPAT.

Berdasarkan KUH Perdata Pasal 1459, jual beli yang dianut di dalam Hukum Perdata hanya bersifat obligatoir, yang artinya jual beli itu belum memindahkan hak milik, hanya baru memberikan hak dan kewajiban kepada kedua belah pihak yaitu, memberikan kepada si pembeli hak untuk menuntut diserahkannya hak milik atas barang yang dijual. ${ }^{10}$ Dengan perkataan lain jual beli yang dianut Hukum Perdata belum memindahkan hak milik adapun hak milik baru berpindah dengan dilakukan penyerahan atau levering yang ditetapkan dengan peraturan lagi.

Berdasarkan uraian tersebut diatas, menurut hukum perdata jual beli tanah terdiri atas 2 (dua) bagian yang saling terpisah satu dengan lainnya, yaitu perjanjian jual belinya dan penyerahan haknya. Maksudnya, status tanah yang diperjualbelikan tersebut masih tetap menjadi hak milik penjual, jika hal kedua belum dilakukan, walaupun hal yang pertama biasanya dengan akta notaris sudah selesai dilakukan. Untuk pembeli bisa mendapatkan perlindungan hukum bahwa telah terjadi perpindahan kepemilikan atas tanah tersebut harus di lakukan yuridis levering. Penyerahan (levering), yaitu cara pemindahan hak milik dari seseorang yang berhak memindahkannya kepada orang lain yang memperoleh hak milik misalnya dengan jual beli. Pasal 1475 KUH Perdata menyatakan "penyerahan adalah suatu pemindahan barang yang telah dijual ke dalam kekuasaan dan kepunyaan pembeli". Penyerahan barang bergerak cukup hanya dengan penyerahan secara nyata, sedangkan penyerahan barang untuk barang tidak bergerak dilakukan dengan cara penyerahan secara yuridis formal. ${ }^{11}$

Dalam kehidupan sehari-hari tidak dapat dipungkiri bahwa masyarakat tidak mengikut sertakan pejabat terkait dalam hal ini PPAT untuk melakukan perbuatan hukum berupa perjanjian jual beli tanah. Perjanjian jual-beli tanah tersebut hanya dibuktikan dengan kwitansi dan saksi-saksi sebagaimana disepakati oleh kedua belah pihak sehingga melahirkan perjanjian jual-beli dibawah tangan. Jika perjanjian jual beli tanah yang dibuat dibawah tangan dikaitkan dengan ketentuan Pasal $1320 \mathrm{KUH}$ Perdata tentang syarat sahnya perjanjian, maka dalam hal ini pembentukan perjanjian jual beli tanah sudah memenuhi syarat $1320 \mathrm{KUH}$ Perdata. Selanjutnya jika dikaitkan

10 Satrianingsih, N. N.P., \& Wirasila, A. A. N. (2018). Peralihan Hak Milik Atass Tanah Melalui Perjanjian Jual-Beli Dibawah Tangan. Kertha Semaya: Journal Ilmu Hukum, 7(6), 1-14. Diakses dari URL : https://ojs.unud.ac.id/index.php/kerthasemaya/article/view/52474

${ }_{11}$ Hanaya, M. P. S. D., \& Sarjana, I. M. (2019). Akibat Hukum Wanprestasi Dalam Peralihan Hak Milik Atas Tanah Melalui Perjanjian Tukar Menukar. Kertha Semaya: Journal Ilmu Hukum, 7(2), 1-14. Diakses dari URL: $\underline{\text { https://ojs.unud.ac.id/index.php/kerthasemaya/article/view/52933 }}$ 
dengan syarat perjanjian jual beli menurut hukum adat yang merupakan dasar pembangunan hukum tanah nasional, maka perjanjian jual beli tanah yang dibuat dibawah tangan telah memenuhi sifat terang dan tunai. Sehingga perjanjian jual beli tanah yang dibuat di bawah tangan tetap sah karena telah memenuhi ketentuan Pasal 1320 KUH Perdata dan sifat perjanjian jual beli tanah hukum adat yang bersif at terang dan tunai.

Walaupun telah sah jika dikaitkan dengan ketentuan Pasal 1320 KUH Perdata dan sifat perjanjian jual beli tanah hukum adat yang bersifat terang dan tunai, pembeli tidak bisa membalik namakan sertifikat tanah tersebut dikarenakan biasanya perjanjian jual beli dibawah tangan transaksi pembayarannya hanya dibuktikan dengan selembar kwintasi dan dihadiri oleh para saksi dari kedua belah pihak saja, bukan akta yang dibuat oleh PPAT. Hal ini sejalan dengan ketentuan Pasal 19 ayat (1) UUPA, Pasal 19 ayat (2) huruf c UUPA, Pasal 37 ayat (1) PP Pendaftaran Tanah dan Pasal 1 angka 20 PP Pendaftaran Tanah, karena untuk dapat dikatakan telah terjadinya pemindah tanganan hak atas tanah melalui jual beli harus adanya akta tersebut. Kwitansi dan keterangan para saksi apabila terjadi sengketa dikemudian hari masih bisa disangkal dan bisa mempunyai kekuatan hukum apabila dikuatkan lagi dengan alat bukti lainnya.

Berdasarkan hal tersebut jual beli atas tanah yang dibuat di bawah tangan yang tidak memenuhi unsur formil dalam hal ini tidak dilakukan di hadapan PPAT dan melahirkan akta yang dibuat oleh PPAT bukanlah jual beli yang mengakibatkan pemindahan hak atas tanah dan juga perbuatan tersebut tidak melahirkan jual beli, Perbuatan tersebut hanya sebatas menimbulkan perjanjian jual beli yang masih harus di ikuti dengan jual beli yang sebenarnya yaitu perjanjian jual beli yang harus dilakukan di hadapan PPAT, jika memang dikehendaki bahwa haknya akan beralih kepada pihak yang telah membayar harga tanahnya. ${ }^{12}$

Merujuk pada Pasal 1459 KUH Perdata, perjanjian jual beli yang dibuat di bawah tangan hanya bersifat obligatoir yang artinyajual beli tersebut belum dapat dikatakan telah terjadinya pemindahan terhadap suatu hak milik, hanya saja baru memberikan hak dan kewajiban kepada kedua belah pihak yaitu, si pembeli diberikan hak untuk menuntut hak milik atas barang yang dijual itu diserahkan kembali. Sesuai dengan Pasal 37 PP Pendaftaran Tanah, setiap dilakukannya peralihan hak atas tanah harus dicatatkan dalam akta jual beli tanah yang dibuat dihadapan PPAT untuk dapat digunakan sebagai bukti telah adanya pengalihan dan pendaftaran peralihan hak atas tanah di kantor Pertanahan. Setiap peralihan hak atas tanah melalui jual beli yang akan didaftarkan di kantor Pertanahan harus dibuktikan dengan adanya akta jual beli yang dibuat dihadapan PPAT. Sehingga, jual beli tanah yang tidak disertai dengan bukti akta jual beli yang dibuat di hadapan PPAT, maka dalam hal ini kantor Pertanahan akan menolak untuk melakukan pengalihan dan pendaftaran tanah tersebut.

\subsection{Pembuktian Perjanjian Jual-Beli Dibawah Tangan Apabila Salah Satu Pihak Meninggal Dunia}

Salah satu unsur terpenting dalam suatu pembuktian perkara perdata adalah keberadaan alat bukti. Di Indonesia menganut sistem hukum pembuktian closed and

12 Salfutra, R. D. (2019). Hukum Agraria Indonesia. Yogyakarta: Thafa Media. h. 158. 
restricted evidentiary system ${ }^{13}$ yang membatasi alat bukti sebagaimana diatur dalam Pasal 164 HIR/284 R.BG dan Pasal 1866 KUH Perdata sebagai berikut: "1. Alat bukti tulisan; 2. Alat bukti saksi; 3. Persangkaan; 4. Pengakuan, dan 5. Sumpah."

Dalam perkara perdata, diantara bukti-bukti lainnya alat bukti tertulis merupakan alat bukti utama, dan yang tertinggi dalam sistem pembuktian. Alat bukti tertulis merupakan alat bukti yang berupa akta. Akta ini dapat dibagi menjadi 2 jenis yaitu: akta otentik dan akta di bawah tangan. Adapun perbedaan akta otentik dan akta dibawah tangan adalah sebagai berikut:

a. Akta otentik

Pasal 1868 KUHPerdata mengatakan bahwa: “akta otentik adalah akta yang (dibuat) dalam bentuk yang ditentukan oleh undang-undang, dibuat oleh atau di hadapan pegawai-pegawai umum yang berkuasa untuk itu, di tempat di mana akta dibuatnya." Apabila diambil intinya, maka yang dimaksud sebagai akta otentik harus memenuhi kriteria sebagai berikut: 14

1) Bentuk sesuai dengan undang-undang;

2) Dibuat oleh atau di hadapan pejabat yang berwenang;

3) Mempunyai pembuktian yang sempurna;

4) Jika akta disangkal mengenai kebenarannya, maka penyangkal harus membuktikan mengenai ketidak benarannya.

b. Akta di bawah tangan

Menurut Pasal 1874 KUH Perdata dan 286 R.Bg menyatakan: “yang dianggap sebagai tulisan di bawah tangan adalah akta yang ditandatangani dibawah tangan, surat, daftar, surat urusan rumah tangga dan tulisan-tulisan yang lain yang dibuat tanpa perantaraan seorang pejabat umum." Ciri dan kekhasan dari akta di bawah tangan, berupa:

1) Bentuknya bebas; 2) Pembuatannya tidak harus di hadapan pejabat umum; 3) Tetap mempunyai kekuatan pembuktian selama tidak disangkal oleh pembuatnya, artinya bahwa isi dari akta tersebut tidak perlu dibuktikan lagi kecuali ada yang bisa membuktikan sebaliknya (menyangkal isinya); 4) Dalam hal harus dibuktikan, maka pembuktian tersebut harus dilengkapi juga dengan saksisaksi dan bukti lainnya. Oleh karena itu, biasanya dalam akta di bawah tangan, sebaiknya dimasukkan 2 orang saksi yang sudah dewasa untuk memperkuat pembuktian.

Berdasarkan penjelasan diatas maka akta di bawah tangan dibuat atas dasar kesepakatan para pihak tanpa perantara pejabat umum yang berwenang. Pembuatan akta di bawah tangan yang tanpa perantara pejabat umum dan hanya atas dasar

${ }^{13}$ Umbas, S. A. (2017). Kedudukan Akta Di Bawah Tangan Yang Telah Dilegalisasi Notaris Dalam Pembuktian Di Pengadilan. Lex Crimen, 6(1), 79-87. Diakses dari URL: https://ejournal.unsrat.ac.id/index.php/lexcrimen/article/view/15089

14Perbedaan Akta Otentik dengan Surat Dibawah Tangan. Tersedia di https://irmadevita.com/2012/perbedaan-akta-otentik-dengan-surat-di-bawah-tangan//. Diakses 15 Juli 2020, pukul 13.00 WITA. 
kesepakatan para pihak saja membuat kekuatan pembuktian akta di bawah tangan tidak mempunyai kekuatan pembuktian yang sempurna dan mengikat seperti halnya kekuatan pembutian akta autentik. Akta di bawah tangan yang hanya mengikat bagi para pihak yang bersepakatan atau yang menandatangi akta tersebut saja, hal ini menyebabkan kekuatan pembuktiannya menjadi bukti permulaan (begin bewijskracht).

Dikaitkan dengan perjanjian di bawah tangan merupakan perjanjian yang disesuaikan dengan kebutuhan para pihak yang berjanji, dan tanpa memerlukan suatu standar baku tertentu. Sehingga dalam kasus perjanjian jual beli tanah kekuatan pembuktiannya hanya antara pihak-pihak yang membuatnya, dan pihak-pihak tersebut mengakui dan tidak menyangkal adanya perjanjian tersebut.

Tetapi apabila perjanjian tersebut tidak diakui oleh para pihak, misalnya salah satu pihak meninggal dunia, ahli waris tidak mengakui perjanjian di bawah tangan sehingga terjadi wanprestasi, ataupun karena mengetahui salah satu pihak yang mengikatkan diri meninggal dunia, maka pihak lainnya ingkar dengan tidak memenuhi prestasinya, maka para pihak harus membuktikan kebenaran peristiwa yang terjadi. Berdasarkan pasal 1865 KUH Perdata atau pasal 163 HIR menyatakan bahwa "Barang siapa yang mengatakan mempunyai barang sesuatu hak atau menyebutkan sesuatu kejadian untuk meneguhkan haknya itu, atau untuk membantah hak orang lain, maka orang itu harus membuktikan adanya hak itu atau kejadian itu". Ketentuan tersebut mengandung arti bahwa pembuktian dapat dibebankan kepada kedua belah pihak baik penggugat maupun tergugat. Pembuktian yang dimaksud disini adalah penggugat wajib membuktikan peristiwa yang diajukannya, sedangkan kewajiban dari pihak tergugat adalah membuktikan kebenaran bantahannya. Penggugat tidak diwajibkan membuktikan kebenaran bantahan tergugat demikian pula sebaliknya tergugat diwajibkan untuk membuktikan kebenaran peristiwa yang diajukan. ${ }^{15}$

Apabila terdapat sangkalan terhadap perjanjian jual beli tanah yang dibuat di bawah tangan oleh ahli waris dari pihak yang meninggal dunia tidak mengakui perjanjian di bawah tangan sehingga terjadi wanprestasi, ataupun karena mengetahui salah satu pihak yang mengikatkan diri meninggal dunia, maka pihak lainnya ingkar dengan tidak memenuhi prestasinya, maka pembuktian dapat dilakukan dengan affidavit oleh saksi-saksi dalam perjanjian jual-beli di bawah tangan tersebut. Affidavit ini harus telah dibuat pada saat jual beli di bawah tangan dilangsungkan. Ini dimaksudkan untuk membuktikan bahwa surat di bawah tangan yang diajukan sebagai alat bukti tersebut benar-benar ditandatangani oleh pihak yang meninggal dunia tersebut.

Affidavit, menurut "Black's Law Dictionary 7th Edition" adalah: "A voluntary declaration of facts written down and sworn to by the minister oaths." Menurut "Webster's New World College Dictionary $4^{\text {th }}$ Edition", affidavit adalah: "A written statement made on oath before the notary public or other person authorized to administer oaths." Sedangkan menurut buku

15 Sunge, M. (2012). Beban Pembuktian Dalam Perkara Perdata. Jurnal Inovasi, 9(2), 1-11. Diakses dari URL: http:// ejurnal.ung.ac.id/index.php/JIN/article/view/715/658 
"Terminologi Hukum Inggris-Indonesia" IPM Ranuhandoko BA sebagai pengarangnya, menyebutkan bahwa affidavit adalah: "Pernyataan tertulis di atas sumpah oleh pembuatnya, di hadapan penguasa yang berwewenang". ${ }^{16}$ Pengertian affidavit secara harafiah yaitu suatu surat keterangan tertulis yang dibuat di bawah sumpah. Kemudian, affidavit juga terdapat dalam ketentuan Undang-Undang Nomor 12 Tahun 2006 tentang Kewarganegaraan (selanjutnya disebut UU Kewarganegaraan). Penggunaan affidavit juga terdapat dalam hukum Indonesia yaitu dalam Peraturan Menteri Hukum Dan Hak Asasi Manusia Republik Indonesia Nomor M.01-HL.03.01 Tahun 2006, affidavit diartikan sebagai "salah satu fasilitas keimigrasian yang diberikan oleh Pemerintah Indonesia kepada seorang anak yang mempunyai paspor asing dan berkewarganegaraan ganda terbatas sesuai dengan UU Kewarganegaraan"; Peraturan Pemerintah Republik Indonesia Nomor 2 Tahun 2007 Tentang Tata Cara Memperoleh, Kehilangan, Pembatalan, Dan Memperoleh Kembali Kewarganegaraan Republik Indonesia. Dalam Putusan Pengadilan Negeri Niaga Nomer 26/Pailit/2004/PN.Niaga.Jkt.Pst tertanggal 13 Agustus 2004 antara Astro-Lite Machinery Pte Ltd selaku Pemohon terhadap PT Kartika Kapuas Sari dan Tn.Budiono selaku Termohon. Dalam putusan tersebut diatas juga dapat ditemuinya penggunaan affidavit.

Affidavit digolongkan sebagai alat bukti tertulis, menurut ketentuan Pasal 1866 KUH Perdata tentang jenis-jenis alat bukti, karena dalam persidangan bentuk fisik yang digunakan sebagai alat bukti adalah tertulis. Affidavit memuat mengenai keterangan saksi terhadap sesuatu yang dilihat dan diketahuinya terkait dengan suatu kejadian atau peristiwa. Affidavit tidak bisa dikategorikan sebagai keterangan saksi karena berdasarkan Putusan MA. 10 Jan. 1957 No. 38 K/Sip/1954 (Keterangan tertulis dibawah sumpah (affidavit) dari seseorang tidak dapat disamakan dengan keterangan saksi di muka hakim), maka affidavit tidak bisa dikategorikan sebagai keterangan saksi, karena affidavit tersebut tidak mempunyai kedudukan yang sama sebagai alat bukti saksi. Affidavit tidak termasuk sebagai alat bukti persangkaan karena persangkaan dikategorikan sebagai alat bukti yang tidak langsung, sedangkan dalam persidangan affidavit yang diajukan sebagai alat bukti merupakan alat bukti yang fisiknya ada dan dalam bentuk tertulis, oleh sebab itu affidavit digolongkan sebagai alat bukti langsung. Berdasarkan hal tersebut dan arti dari affidafit, dapat ditarik bahwa affidavit adalah suatu alat bukti tertulis yang didalamnya memiliki unsur alat bukti lain yaitu berupa saksi dan sumpah.

Dikaitkan dengan Pasal 15 Undang-Undang Nomor 2 Tahun 2014 tentang Perubahan Atas Undang-Undang Nomor 30 Tahun 2004 Tentang Jabatan Notaris yang menyatakan kewenangan notaris diantaranya:

(1) Notaris berwenang membuat Akta autentik mengenai semua perbuatan, perjanjian, dan penetapan yang diharuskan oleh peraturan perundang-undangan dan/atau yang dikehendaki oleh yang berkepentingan untuk dinyatakan dalam

16 Tentang Affidavit. Tersedia di https://www.hukumonline.com/klinik/detail/ ulasan/ cl3371/tentang-affidavit/. Diakses 15 Juli 2020, pukul 13.00 WITA. 
Akta autentik, menjamin kepastian tanggal pembuatan Akta, menyimpan Akta, memberikan grosse, salinan dan kutipan Akta, semuanya itu sepanjang pembuatan Akta itu tidak juga ditugaskan atau dikecualikan kepada pejabat lain atau orang lain yang ditetapkan oleh undangundang.

(2) Selain kewenangan sebagaimana dimaksud pada ayat (1), Notaris berwenang pula: a. mengesahkan tanda tangan dan menetapkan kepastian tanggal surat di bawah tangan dengan mendaftar dalam buku khusus; b. membukukan surat di bawah tangan dengan mendaftar dalam buku khusus; c. membuat kopi dari asli surat di bawah tangan berupa salinan yang memuat uraian sebagaimana ditulis dan digambarkan dalam surat yang bersangkutan; d. melakukan pengesahan kecocokan fotokopi dengan surat aslinya; e. memberikan penyuluhan hukum sehubungan dengan pembuatan Akta; f. membuat Akta yang berkaitan dengan pertanahan; atau g. membuat Akta risalah lelang.

(3) Selain kewenangan sebagaimana dimaksud pada ayat (1) dan ayat (2), Notaris mempunyai kewenangan lain yang diatur dalam peraturan perundang-undangan.

Berdasarkan ketentuan mengenai kewenangan Notaris tersebut, pengambilan sumpah terkait dibuatnya affidavit bukan merupakan kewenangan dari Notaris. Kewenangan untuk mengambil sumpah adalah kewenangan pengadilan. Sehingga pembuatan affidavit merupakan kewenangan dari Pengadilan Negeri. Penghadap dan minimal 2 (dua) orang saksi datang ke pengadilan negeri untuk disumpah oleh hakim. Setelah disumpah, maka pengadilan mengeluarkan berita acara sumpah dan affidavit. Affidavit memuat fakta-fakta dan keterangan-keterangan dari suatu kesaksian yang mana faktafakta tersebut merupakan sesuatu yang konkret dan logis, sehingga affidavit harus mengandung kebenaran yang dapat diterima akal (common sense) akan suatu peristiwa.

Dalam hal kekuatan pembuktiannya maka affidavit dapat dikategorikan sebagai alat bukti pelengkap, sebagai alat bukti dalam persidangan. Dalam hal ini sepanjang dugaan adanya kepalsuan itu tidak dapat dibuktikan pihak lawan, maka affidavit harus dianggap benar serta dapat diterima oleh hakim dalam persidangan. Dikaitkan dalam hal terdapat sangkalan mengenai dibuatnya perjanjian jual beli tanah secara di bawah tangan oleh ahli waris dari pihak yang meninggal dunia, maka affidavit dapat dijadikan bukti pelengkap dari akta jual beli yang dibuat di bawah tangan oleh para pihak. Sehingga, dengan adanya affidavit dapat memberikan perlindungan dan kepastian hukum serta keadilan dimata hukum dalam hal perjanjian jual-beli tanah dalam bentuk akta di bawah tangan yang dianggap rentan.

\section{Kesimpulan}

Perjanjian jual-beli tanah yang dibuat di bawah tangan sah menurut ketentuan Pasal 1320 KUH Perdata dan syarat suatu perjanjian jual-beli tanah berdasarkan hukum adat, namun berdasarkan Pasal 1459 KUH Perdata, Pasal 19 ayat (1) UUPA, Pasal 19 ayat (2) huruf c UUPA dan Pasal 37 ayat (1) PP Pendaftaran Tanah, perjanjian jual-beli yang dibuat di bawah tangan belum memindahkan hak milik atas tanah hanya baru memberikan hak dan kewajiban kepada kedua belah pihak yaitu, memberikan kepada si pembeli hak untuk menuntut diserahkannya hak milik atas barang yang dijual. Pembuktian perjanjian jual-beli di bawah tangan apabila salah satu pihak meninggal 
dunia dapat dilakukan dengan surat keterangan yang tertulis dibuat di bawah sumpah (affidavit) sebagai alat bukti pelengkap.

\section{Daftar Pustaka/Daftar Referensi}

\section{Buku:}

Diantha, I. M. P. (2016). Metodologi Penelitian Hukum Normatif dalam Justifikasi Teori Hukum. Jakarta: Prenada Media.

Hajar, M. (2015). Model-Model Pendekatan Dalam Penelitian Hukum dan Fiqh. Pekanbaru: UIN Suska Riau.

Salim. H.S. (2014). Perancangan Kontrak dan Memorandum of Understanding (MOU). Edisi Ke-6. Jakarta: Sinar Grafika.

Salfutra, R. D. (2019). Hukum Agraria Indonesia. Yogyakarta: Thafa Media.

\section{Jurnal:}

Dinaryanti, A. R. (2013). Tinjauan Yuridis Legalisasi Akta Di Bawah Tangan Oleh Notaris. Jurnal Ilmu Hukum Legal Opinion, 1(3), 2. Diakses dari URL: https://www.neliti.com/publications/150428/tinjauan-yuridis-legalisasi-aktadi-bawah-tangan-oleh-notaris.

Gumanti, R. (2012). Syarat Sahnya Perjanjian (Ditinjau Dari Kuhperdata). Jurnal Pelangi Ilmu, 5(1), 1-13. Diakses dari URL: http://ejurnal.ung.ac.id/index.php/JPI/article/view/900/840.

Hanaya, M. P. S. D., \& Sarjana, I. M. (2019). Akibat Hukum Wanprestasi Dalam Peralihan Hak Milik Atas Tanah Melalui Perjanjian Tukar Menukar. Kertha Semaya: Journal Ilmu Hukum, 7(2), 1-14. Diakses dari URL: https://ojs.unud.ac.id/index.php/kerthasemaya/article/view/52933.

Santoso, U. (2012). Jual-Beli Tanah Hak Milik Yang Bertanda Bukti Petuk Pajak Bumi (Kutipan Letter C). Jurnal Perspektif Fakultas Hukum Universitas Airlangga Surabaya, 17(2), 62-69. DOI: http://dx.doi.org/10.30742/perspektif.v17i2.95.

Sari, E. P., Sihabudin., \& Winarno, B. (2015). Kekuatan Pembuktian Affidavit sebagai Alat Bukti Surat. Jurnal Hukum, 1-22. Diakses dari URL: http://hukum.studentjournal.ub.ac.id/index.php/hukum/article/view/1194/ $\underline{1180}$.

Satrianingsih, N. N. P., \& Wirasila, A. A. N. (2018). Peralihan Hak Milik Atas Tanah Melalui Perjanjian Jual Beli Dibawah Tangan. Kertha Semaya: Journal Ilmu Hukum, 7(6), 1-14. C Diakses dari URL
https://ojs.unud.ac.id/index.php/kerthasemaya/article/view/52474. 
Sunge, M. (2012). Beban Pembuktian Dalam Perkara Perdata. Jurnal Inovasi, 9(2), 1-11. Diakses dari URL: http://ejurnal.ung.ac.id/index.php/JIN/article/view/715/658.

Umbas, S. A. (2017). Kedudukan Akta Di Bawah Tangan Yang Telah Dilegalisasi Notaris Dalam Pembuktian Di Pengadilan. Lex Crimen, 6(1), 79-87. Diakses dari URL: https://ejournal.unsrat.ac.id/index.php/lexcrimen/article/view/15089.

Widiadnyani, I. G. A., Windari, R. A.., \& Suditmaka, K. (2018). Implikasi Yuridis Jual Beli Tanah Adat Melalui Perjanjian Dibawah Tangan Dalam Perspektif Undang-Undang Pokok Agraria. Jurnal Komunitas Yustitia, 1(1). 1-10. Diakses dari

URL: https://ejournal.undiksha.ac.id/index.php/jatayu/article/view/23753/14393.

\section{Peraturan Perundang-Undangan :}

Kitab Undang-Undang Hukum Perdata, Soedharyo Soimin, 2014, Sinar Grafika, Jakarta.

Undang-Undang Nomor 5 Tahun 1960 tentang Peraturan Dasar Pokok-Pokok Agraria (Lembaran Negara 1960-104 Tambahan Lembaran Negara Nomor 2043).

Peraturan Pemerintah Republik Indonesia Nomor 24 Tahun 1997 tentang Pendaftaran Tanah (Lembaran Negara Republik Indonesia Tahun 1997 Nomor 59 Tambahan Lembaran Negara Republik Indonesia Nomor 3696).

\section{Website:}

Perbedaan Akta Otentik dengan Surat Dibawah Tangan. Tersedia di https://irmadevita.com/2012/perbedaan-akta-otentik-dengan-surat-di-bawahtangan/. Diakses 15 Juli 2020, pukul 13.00 WITA.

Putusan Nomor: 383/ Pdt.G/2018/PN. Dps. Tersedia di https://putusan3.mahkamahagung.go.id/direktori/putusan/5258a86b48ea4d b2939cfdbc1637a40e.html. Diakses 14 Juli 2020, pukul 09.00 WITA.

Tentang Affidavit. Tersedia di https://www.hukumonline.com/klinik/detail/ ulasan/ cl3371/tentang-affidavit/. Diakses 15 Juli 2020, pukul 13.00 WITA. 